\title{
NEXT STOP: UNDERGROUND. VARIABLE DEGREES AND VARIETY OF REASONS FOR CAVE PENETRATION IN TERRESTRIAL GASTROPODS
}

\author{
NASLEDNJA POSTAJA: PODZEMLJE. \\ RAZLIČNE STOPNJE IN RAZLIČNI RAZLOGI PRODIRANJA \\ KOPENSKIH POLŽEV V JAME
}

\author{
Alexander M. WEIGAND ${ }^{1,2}$
}

\begin{abstract}
UDC 594.3:551.44

Alexander M. Weigand: Next Stop: Underground. Variable degrees and variety of reasons for cave penetration in terrestrial gastropods

Cave-dwelling animals can be classified based on their occurrence in and relationship to the subterranean environment. Subsurface distribution data and studies addressing the initial causes for animals to enter underground habitats are sparse. By retrieving occurrence data from two voluntary biospeleological collections in Central Germany, the degree of cave penetration in terrestrial gastropods was investigated, thus to infer potential evolutionary drivers. In total, 66 identified gastropod species entered the subterranean environment with 23 of the species also recorded from the dark zone. Gastropods possessed variable degrees of cave penetration and no obligate cave forms were observed. A decline of occurrence records from the entrance to the dark zone was the most prominent pattern. Nevertheless, several species were collected from all three light zones (i.e. entrance, transition and dark). A variety of potential reasons can be inferred to explain their subsurface appearance: exploitation of alternative food sources, aphotic above-ground movement, mating sites, temporal, seasonal and long-term refugia, and chance. Moreover, the results imply a frequent migration of species between the interconnected light zones and the surface. Consequently, terrestrial gastropods should be considered when investigating the origin and importation of allochthonous resources in caves.
\end{abstract}

Keywords: Gastropoda, subterranean environment, ecology, distribution data, cave colonization, speciation.

\author{
Izvleček \\ UDK 594.3:551.44 \\ Alexander M. Weigand: Naslednja postaja: podzemlje. Razli- \\ čne stopnje in različni razlogi prodiranja kopenskih polžev $v$ \\ jame
}

Podzemeljske živali lahko opredelimo glede na njihovo pojavljanje v podzemeljskem okolju in odnos do tega okolja. Podatki o razširjenosti živali v podzemlju in študije, ki obravnavajo vzroke za kolonizacijo podzemlja so redki. Stopnja prodiranja kopenskih polžev $\mathrm{v}$ jame in morebitni evolucijski vzroki so bili proučevani na podlagi dveh biospeleoloških zbirk v osrednji Nemčiji. Skupno je bilo določenih 66 vrst polžev, ki zaidejo v podzemlje, od tega 23 vrst iz temnih predelov podzemlja. Čeprav polži kažejo različne stopnje prodiranja $\mathrm{v}$ jame, podzemeljska oblika polžev ni bila ugotovljena. Najpogostejši vzorec razširjenosti je bil upadanje njihovega pojavljanja od vhoda proti notranjosti, čeprav je bilo po nekaj vrst vedno ugotovljenih $\mathrm{v}$ vseh treh conah: na vhodu, na prehodu med svetlo in temno cono ter $\mathrm{v}$ temni coni. Možnih je več razlogov, zaradi katerih se pojavijo $\mathrm{v}$ podzemlju: izkoriščanje alternativnih virov hrane, afotično gibanje na površju, paritvena mesta, začasno, sezonsko ali dolgotrajno zatočišče ter priložnost. Rezultati kažejo na pogosto migracijo vrst med posameznimi conami in površjem. Posledično bi bilo potrebno kopenske polže upoštevati pri raziskavah izvora in vnosa alohtonih virov v jame.

Ključne besede: Gastropoda (polži), podzemeljsko okolje, ekologija, podatki o razširjenosti, kolonizacija jam, speciacija.

${ }^{1}$ Goethe-University, Institute for Ecology, Evolution and Diversity, Department of Phylogeny \& Systematics,

Max-von-Laue Str. 13, 60438 Frankfurt am Main

${ }^{2}$ Croatian Biospeleological Society, Demetrova 1, 10000 Zagreb, Croatia, e-mail: weiganda@gmx.net

Received/Prejeto: 08.03.2013 


\section{INTRODUCTION}

Since the first nominal description of a cave-dwelling animal, the blind cave salamander Proteus anguinus (Laurenti 1768), subterranean organisms have attracted people's attention. Possessing a life in permanent darkness, this curiosity immediately can be imagined. But even more so, the perception is frequently underscored by a strongly modified, sometimes bizarre morphology. Cavedwelling adaptive features include the (often complete) reduction of eyes and body pigmentation (= reductive troglomorphies) resulting in 'blind albinos' or the elongation of body appendages and an improved extra-optical sensory system (= constructive troglomorphies; Protas \& Jeffery 2012). However, not all cave species exhibit a troglomorphic appearance (Bichuette \& Trajano 2003). Subterranean organisms can be ecologically classified depending on their occurrence in and relationship to the subterranean habitat (Sket 2008). Obligate cave forms (= eutroglobionts) are restricted and highly adapted to a life in darkness, whereas in some occasions, epigean animals may accidentally occur in the subterranean environment (= eutrogloxenes). Both extremes of this ecological continuum are connected by all levels of intermediate forms. Based on the formation of stable or temporal subterranean populations, they are commonly referred to as eutroglophiles or subtroglophiles, respectively.

To explain the initial phases of cave colonization and speciation between surface and subsurface popula- tions, unsuitable environmental conditions on the surface (Climate Relict Hypothesis) and the exploitation of alternative resources (Adaptive Shift Hypothesis) have been discussed as evolutionary drivers (for a review see Juan et al. 2010). Subsequently, speciation of underground lineages may have been triggered by subsurface dispersal or vicariance events leading to the formation of allopatric populations. More recently, a combination of both non-exclusive processes has been considered (Culver et al. 2007; Weigand et al. 2013). Besides studies addressing speciation processes within the underground realm or to a surface population, causes for the initial phase of cave colonizations have been studied less intensively (Camp \& Jensen 2007) although frequently reconstructed from phylogenetic patterns (Leys et al. 2003; Howarth \& Hoch 2005; Cooper et al. 2007).

In this survey, the affinity of gastropod species to the subterranean environment is investigated with the aim to infer potential evolutionary drivers for their occurrence in underground habitats. Since gastropods are chemically oriented organisms, they do not have to overcome the disadvantage imposed by visual orientation in caves (Culver \& Pipan 2009). As a consequence, a certain number of surface litter species are expected to occur in caves, thus representing multiple case studies.

\section{VARIABLE DEGREES OF SUBTERRANEAN PENETRATION}

Observation records of cave-dwelling terrestrial gastropods were retrieved from two voluntary collections: from the Biospeleological Register of the Hesse Federation for Cave and Karst Research (HES; Zaenker 2008; Reiss et al. 2009a) and for the region of Rhineland-Palatinate + Saarland (RP + SAR; Weber 2012) (Fig. 1). The geology of the study area is very heterogeneous but primarily consists of limestone, argillaceous shale, slate and red sandstone. In addition to natural objects (i.e. caves, deep fissures), species were recorded from artificial cavities (i.e. bunkers, tunnels, mines) totaling 3352 investigated terrestrial objects (i.e. without springs, groundwater samples). During each visit $(\mathrm{N})$, terrestrial gastropods were recorded and classified based on their occurrence in the entrance (E), transition (T) or dark zone (D) of the subterranean environment. Thereby, species observations are qualitative records for a given zone rather than representing count data of specimens. In some occasions, specimens of a single species were collected in multiple zones during a visit (i.e. $\mathrm{N}=1$ but more than one light zone with an occurrence record). Taxonomic identification is based on conchological and/or anatomical characteristics and was primarily performed by S. Zaenker, D. Weber, K. Bogon and $\mathrm{H}$. Kappes. Taxonomic nomenclature is according to Fauna Europaea (2012). For species with $\mathrm{N} \geq 15$ and occurrence records from all three light zones, a $\mathrm{Chi}^{2}$-test was conducted in SPSS 12.0 (IBM) to test for equal frequency distributions. In total, 66 gastropod species were found within the subterranean environment (Tab. 1, Fig. 2), i.e. at least penetrating the entrance zone. An amount of $58 \%(38 / 66)$ of the identified species was shared by both geographical regions (i.e. HES vs. RP + SAR). Notable exceptions refer to Arion ater, Arion silvaticus, Ena montana and Pomatias elegans only recorded from HES and Arion rufus and Phenacolimax major, which were only present in RP + SAR. Daudebardia rufa was almost en- 


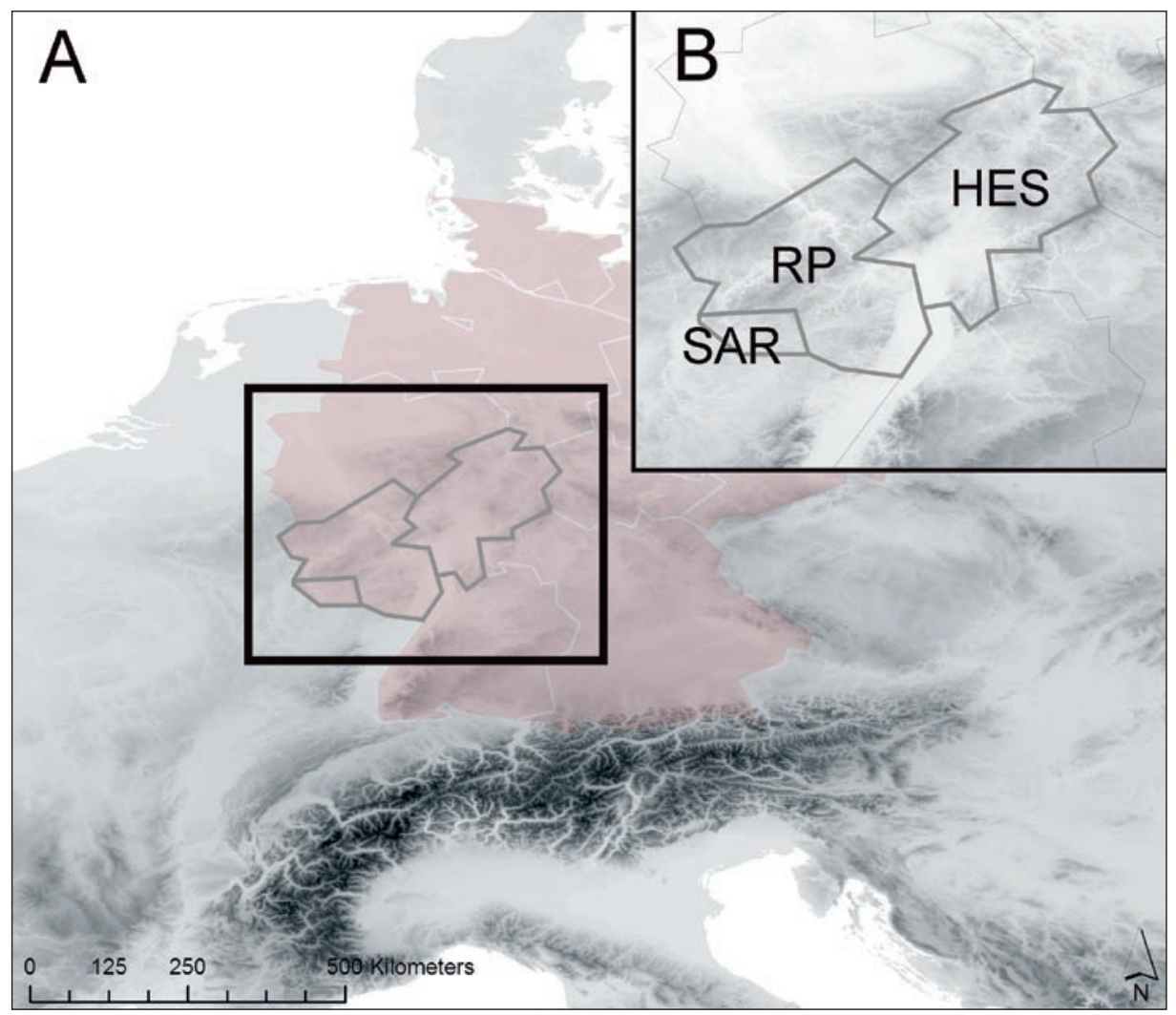

Fig. 1: Overview of the study area. A: The map indicates the geographical location of the two voluntary biospeleological collections for Hesse (HES) and Rhineland-Palatinate + Saarland $(R P+S A R)$ in Germany (colored in red). B: Detailed geographical overview of the study area.

tirely restricted to HES (73 observations) with a single specimen found in SAR + RP. The dark zone was penetrated by $35 \%(23 / 66)$ of all species. Although they only constituted $13 \%$ of the total records (706/5589), Boettgerilla pallens and Oxychilus spp. accounted for $56 \%$ of all dark zone observations.

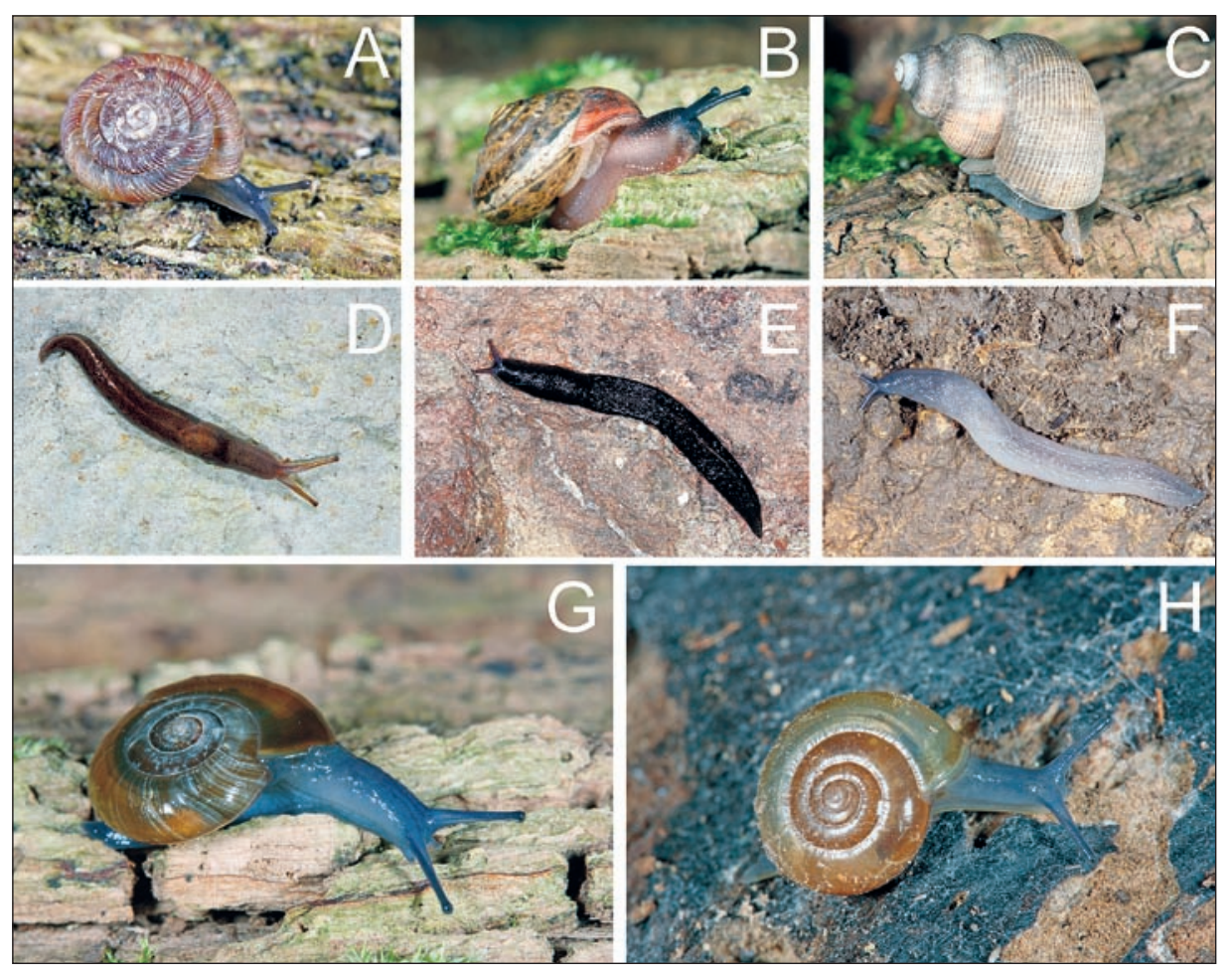

Fig. 2: Terrestrial gastropod species penetrating the subterranean environment. A: Discus rotundatus; B: Monachoides incarnatus; C: Pomatias elegans; D: Lehmannia marginata; E: Limax cinereoniger; F: Boettgerilla pallens; G: Oxychilus draparnaudi; H: Oxychilus cellarius. Copyright of the individual pictures: Klaus Bogon. 
Tab 1: Subsurface distribution data of terrestrial gastropod species. Distribution records for the different light zones are separated for two voluntary collections: the biospeleological state register of Hesse (HES) and a private collection for the region of Rhineland-Palatinate + Saarland $(R P+S A R)$. N: number of visits; S: surface record; E: entrance zone record; T: transition zone record; D: dark zone record. Species with records in the $E+T+D$ zone $(N \geq 10)$ were tested by a Chi ${ }^{2}$-test.

\begin{tabular}{|c|c|c|c|c|c|c|c|c|c|c|c|c|}
\hline$\#$ & taxon & morphospecies & $N$ & $S$ & E & $T$ & $D$ & $N$ & $E$ & $T$ & $D$ & $p\left(\mathrm{Chi}^{2}\right)$ \\
\hline & & & & & HES & \multicolumn{7}{|c|}{$\mathrm{RP}+\mathrm{SAR}$} \\
\hline 1 & Agriolimacidae & Deroceras reticulatum (O. F. Müller, 1774) & 2 & 0 & 2 & 0 & 0 & 1 & 1 & 0 & 0 & \\
\hline 2 & Arionidae & Arion sp. & 513 & 376 & 119 & 66 & 13 & 41 & 25 & 20 & 1 & $<0.001$ \\
\hline 3 & & Arion ater (Linnaeus, 1758) & 18 & 2 & 12 & 5 & 1 & & & & & 0.006 \\
\hline 4 & & Arion circumscriptus Johnston, 1828 & 6 & 0 & 6 & 1 & 0 & 4 & 3 & 1 & 0 & \\
\hline 5 & & Arion distinctus J. Mabille, 1868 & 3 & 0 & 3 & 0 & 0 & & & & & \\
\hline 6 & & Arion fasciatus (Nilsson, 1823) & 1 & 0 & 1 & 0 & 0 & 1 & 0 & 1 & 0 & \\
\hline 7 & & $\begin{array}{l}\text { Arion fuscus (O.F. Müller, 1774) / A. subfuscus } \\
\text { (Draparnaud, 1805) }\end{array}$ & 10 & 3 & 7 & 2 & 0 & 1 & 0 & 1 & 0 & \\
\hline 8 & & Arion cf. intermedius Normand, 1852 & 4 & 0 & 3 & 2 & 0 & & & & & \\
\hline 9 & & Arion lusitanicus J. Mabille, 1868 & 16 & 0 & 14 & 3 & 1 & 2 & 0 & 2 & 0 & 0.001 \\
\hline 10 & & Arion rufus (Linnaeus, 1758) & & & & & & 38 & 13 & 25 & 2 & $<0.001$ \\
\hline 11 & & Arion silvaticus Lohmander, 1937 & 16 & 1 & 11 & 4 & 1 & & & & & 0.007 \\
\hline 12 & Boettgerillidae & Boettgerilla pallens Simroth, 1912 & 92 & 24 & 27 & 32 & 34 & 14 & 5 & 6 & 4 & 0.717 \\
\hline 13 & Bradybaenidae & Fruticicola fruticum (O. F. Müller, 1774) & 6 & 3 & 2 & 1 & 0 & & & & & \\
\hline 14 & Carychiidae & $\begin{array}{l}\text { Carychium tridentatum (Risso, 1826) / } \\
\text { C. minimum O. F. Müller, } 1774\end{array}$ & 850 & 834 & 16 & 0 & 0 & 4 & 1 & 0 & 2 & \\
\hline 15 & Chondrinidae & Chondrina avenacea (Bruguière, 1792) & 1 & 0 & 1 & 0 & 0 & & & & & \\
\hline 16 & Clausiliidae & Alinda biplicata (Montagu, 1803) & 13 & 6 & 5 & 3 & 0 & 7 & 7 & 0 & 0 & \\
\hline 17 & & Balea perversa (Linnaeus, 1758) & 4 & 1 & 3 & 0 & 0 & & & & & \\
\hline 18 & & Clausilia bidentata (Strøm, 1765) & & & & & & 19 & 18 & 1 & 0 & \\
\hline 19 & & Clausilia rugosa (Draparnaud, 1801) & 10 & 0 & 10 & 0 & 0 & 5 & 4 & 2 & 0 & \\
\hline 20 & & Cochlodina laminata (Montagu, 1803) & 8 & 2 & 6 & 0 & 0 & 10 & 8 & 1 & 1 & \\
\hline 21 & & Macrogastra attenuata (Rossmässler, 1835) & & & & & & 2 & 2 & 0 & 0 & \\
\hline 22 & & Macrogastra ventricosa (Draparnaud, 1801) & & & & & & 1 & 0 & 1 & 0 & \\
\hline 23 & Cochlicopidae & Cochlicopa sp. & 84 & 73 & 10 & 9 & 0 & 4 & 2 & 2 & 0 & \\
\hline 24 & & Cochlicopa lubrica (O. F. Müller, 1774) & 9 & 9 & 0 & 0 & 0 & 9 & 8 & 1 & 0 & \\
\hline 25 & & Cochlicopa lubricella (Rossmässler, 1834) & 4 & 1 & 3 & 2 & 0 & & & & & \\
\hline 26 & & Azeca goodalli (A. Férussac, 1821) & 24 & 20 & 4 & 0 & 0 & & & & & \\
\hline 27 & Daudebardiidae & Daudebardia rufa (Draparnaud, 1805) & 73 & 63 & 10 & 6 & 0 & 1 & 0 & 1 & 0 & \\
\hline 28 & Enidae & Ena montana (Draparnaud, 1801) & 35 & 22 & 11 & 5 & 1 & & & & & 0.011 \\
\hline 29 & & Merdigera obscura (O. F. Müller, 1774) & 2 & 0 & 2 & 0 & 0 & 2 & 2 & 0 & 0 & \\
\hline 30 & & Zebrina detrita (0. F. Müller, 1774) & & & & & & 1 & 1 & 0 & 0 & \\
\hline 31 & Euconulidae & Euconulus sp. & 39 & 39 & 0 & 0 & 0 & & & & & \\
\hline 32 & & Euconulus fulvus (O. F. Müller, 1774) & 88 & 82 & 6 & 2 & 0 & 6 & 3 & 3 & 0 & \\
\hline 33 & Ferussaciidae & Cecilioides acicula (0. F. Müller, 1774) & 10 & 9 & 1 & 0 & 0 & & & & & \\
\hline 34 & Helicidae & Cepaea sp. & 49 & 17 & 28 & 12 & 2 & 12 & 10 & 2 & 0 & $<0.001$ \\
\hline 35 & & Cepaea hortensis (O. F. Müller, 1774) & 48 & 17 & 21 & 14 & 4 & 9 & 6 & 3 & 0 & $<0.001$ \\
\hline 36 & & Cepaea nemoralis (Linnaeus, 1758) & 48 & 11 & 28 & 13 & 5 & 34 & 18 & 13 & 4 & $<0.001$ \\
\hline
\end{tabular}


NEXT STOP: UNDERGROUND. VARIABLE DEGREES AND VARIETY OF REASONS FOR CAVE PENETRATION IN ...

\begin{tabular}{|c|c|c|c|c|c|c|c|c|c|c|c|c|}
\hline$\#$ & taxon & morphospecies & $N$ & $S$ & $E$ & $T$ & $D$ & $N$ & $E$ & $T$ & $D$ & $p\left(C h i^{2}\right)$ \\
\hline 37 & & Arianta arbustorum (Linnaeus, 1758) & 21 & 15 & 6 & 3 & 0 & 2 & 2 & 0 & 0 & \\
\hline 38 & & Helicigona lapicida (Linnaeus, 1758) & 95 & 3 & 85 & 23 & 3 & 25 & 17 & 8 & 0 & $<0.001$ \\
\hline 39 & & Helix pomatia Linnaeus, 1758 & 23 & 4 & 12 & 7 & 3 & 23 & 15 & 7 & 2 & $<0.001$ \\
\hline 40 & & $\begin{array}{l}\text { Isognomostoma isognomostomos } \\
\text { (Schröter, 1784) }\end{array}$ & 22 & 7 & 14 & 4 & 0 & & & & & \\
\hline 41 & Helicodontidae & Helicodonta obvoluta (O. F. Müller, 1774) & 107 & 33 & 60 & 36 & 2 & 34 & 21 & 15 & 1 & $<0.001$ \\
\hline 42 & Hygromiidae & Helicella sp. & & & & & & 3 & 3 & 0 & 0 & \\
\hline 43 & & Trochulus sp. & 125 & 106 & 16 & 9 & 1 & 2 & 2 & 0 & 0 & $<0.001$ \\
\hline 44 & & Trochulus hispidus (Linnaeus, 1758) & 6 & 2 & 3 & 1 & 0 & 2 & 1 & 1 & 0 & \\
\hline 45 & & Trochulus plebeius (Draparnaud, 1805) & 4 & 4 & 0 & 0 & 0 & & & & & \\
\hline 46 & & Trochulus sericeus (Draparnaud, 1801) & & & & & & 1 & 1 & 0 & 0 & \\
\hline 47 & & Monachoides incarnatus (O. F. Müller, 1774) & 511 & 399 & 95 & 50 & 7 & 49 & 39 & 10 & 0 & $<0.001$ \\
\hline 48 & Limacidae & & 191 & 148 & 39 & 18 & 4 & 26 & 14 & 15 & 1 & $<0.001$ \\
\hline 49 & & Lehmannia marginata (O. F. Müller, 1774) & 16 & 0 & 15 & 4 & 2 & 4 & 4 & 0 & 0 & $<0.001$ \\
\hline 50 & & Limax cinereoniger Wolf, 1803 & 31 & 0 & 25 & 10 & 4 & 83 & 40 & 42 & 5 & $<0.001$ \\
\hline 51 & & Limax maximus Linnaeus, 1758 & 59 & 21 & 30 & 21 & 5 & 23 & 12 & 16 & 3 & $<0.001$ \\
\hline 52 & Milacidae & Tandonia rustica (Millet, 1843) & 6 & 2 & 3 & 1 & 1 & 2 & 1 & 0 & 1 & \\
\hline 53 & Orculidae & Sphyradium doliolum (Bruguière, 1792) & 1 & 0 & 1 & 1 & 0 & 1 & 1 & 0 & 0 & \\
\hline 54 & Oxychilidae & Oxychilus sp. & 67 & 24 & 29 & 23 & 10 & 31 & 10 & 18 & 4 & 0.001 \\
\hline 55 & & Oxychilus alliarius (J. S. Miller, 1822) & 6 & 3 & 2 & 0 & 1 & & & & & \\
\hline 56 & & Oxychilus cellarius (O. F. Müller, 1774) & 167 & 7 & 98 & 88 & 48 & 244 & 87 & 136 & 38 & $<0.001$ \\
\hline 57 & & Oxychilus draparnaudi (H. Beck, 1837) & 12 & 0 & 10 & 6 & 1 & 73 & 31 & 36 & 10 & $<0.001$ \\
\hline 58 & & Aegopinella nitens (Michaud, 1831) & 5 & 2 & 2 & 1 & 0 & 3 & 3 & 0 & 0 & \\
\hline 59 & & Aegopinella nitidula (Draparnaud, 1805) & 15 & 9 & 6 & 1 & 0 & 2 & 2 & 0 & 0 & \\
\hline 60 & & Aegopinella pura (Alder, 1830) & 15 & 11 & 4 & 1 & 0 & 1 & 0 & 1 & 0 & \\
\hline 61 & & Nesovitrea hammonis (Strøm, 1765) & 5 & 3 & 2 & 1 & 0 & 3 & 3 & 0 & 0 & \\
\hline 62 & Patulidae & Discus rotundatus (O. F. Müller, 1774) & 655 & 386 & 226 & 108 & 19 & 299 & 174 & 132 & 14 & $<0.001$ \\
\hline 63 & Pomatiidae & Pomatias elegans (0. F. Müller, 1774) & 13 & 2 & 11 & 3 & 0 & & & & & \\
\hline 64 & Pristilomatidae & Vitrea crystallina (O. F. Müller, 1774) & 6 & 5 & 1 & 0 & 0 & 2 & 1 & 1 & 0 & \\
\hline 65 & Pupillidae & Pupilla muscorum (Linnaeus, 1758) & 2 & 1 & 1 & 0 & 0 & & & & & \\
\hline 66 & Succineidae & Oxyloma elegans (Risso, 1826) & 7 & 6 & 0 & 1 & 0 & & & & & \\
\hline 67 & & Succinella oblonga (Draparnaud, 1801) & 6 & 5 & 1 & 0 & 0 & & & & & \\
\hline 68 & Valloniidae & Vallonia sp. & & & & & & 1 & 1 & 0 & 0 & \\
\hline 69 & & Vallonia pulchella (O. F. Müller, 1774) & 13 & 12 & 1 & 0 & 0 & & & & & \\
\hline 70 & & Acanthinula aculeata (O. F. Müller, 1774) & 15 & 13 & 2 & 1 & 0 & & & & & \\
\hline 71 & Vitrinidae & Eucobresia diaphana (Draparnaud, 1805) & 4 & 2 & 1 & 2 & 0 & & & & & \\
\hline 72 & & Phenacolimax major (A. Férussac, 1807) & & & & & & 77 & 52 & 26 & 0 & \\
\hline 73 & & Vitrina pellucida (O. F. Müller, 1774) & 14 & 5 & 8 & 2 & 0 & 12 & 7 & 3 & 2 & 0.002 \\
\hline \multirow[t]{2}{*}{74} & & Vitrinobrachium breve (A. Férussac, 1821) & & & & & & 2 & 0 & 2 & 0 & \\
\hline & & $\Sigma$ & 4331 & 2855 & 1181 & 608 & 173 & 1258 & 681 & 555 & 95 & \\
\hline
\end{tabular}




\section{VARIETY OF REASONS FOR SUBTERRANEAN PENETRATION}

Knowledge about the occurrence of a species among different light environments (i.e. entrance, transition and dark zone) is important to understand the selective pressure of the subterranean environment imposed on the gene pool of the population. Numerous gastropod species were (sporadically) found within the subterranean environment. No true obligate cave forms were observed and only one third of all species possessed records in the dark zone. Those species were generally collected from other light zones as well. An unequal distribution of observation records with a peak in the entrance zone and decline to the dark zone was the most common pattern. One striking exception refers to the slug Boettgerilla pallens, for which an equal frequency distribution cannot be rejected ( $\mathrm{Chi}^{2}$-test, $\mathrm{p}=0.717$ ). The majority of observations for this species originated from the transition and dark zone. Typically known from soil samples, B. pallens demonstrates a rather limited mobility by grounddwelling or moving in earthworm burrows (Gunn 1992). In the study area, however, it was found moving aboveground and climbing on walls in the subterranean environment. Supposedly, the species has recently spread from the Caucasus region over large parts of Central Europe. Even sightings from North- (Canada) and SouthAmerica (Columbia) exist (Reise et al. 2000; Hausdorf 2002). Although human-mediated dispersal is considered to explain the rapid pan-European colonization and transatlantic dispersal, this study points to a local aboveground movement within the more spacious, aphotic subterranean environment. This behavior may enable a faster establishment and spread after arrival.

Specimens of the carnivorous and omnivorous taxa Oxychilus and Boettgerilla constituted the majority of dark zone observations (56\%). The penetration of nonsurface habitats in those groups can be related to the exploitation of alternative food sources. Species of both taxa are known to prey on small gastropods and egg clutches. In particular, Boettgerilla pallens, Oxychilus cellarius and Oxychilus draparnaudi were recorded to feed on arionid eggs (Daxl 1967; Gunn 1992; von Proschwitz 1994). Their prey, juvenile slugs of the Arionidae and Limacidae, were frequently encountered in the subterranean environments of the studied region. The presence of juvenile slugs either suggests an underground colonization during infancy or a subsurface egg deposition with in situ hatching. Similar observations were recorded from caves in Luxembourg, including juvenile Boettgerilla for which egg-laying is known to occur below ground (Gunn 1992; Renker et al. 2012; Renker et al. 2013). Heller and Dolev (1993) hypothesized that "crevices might be a suitable habitat for land snails in which the hatching period, and period of juvenile growth, are very long". By implication, the prolonged development could be seen as a result of the less nutrient rich subsurface conditions.

Avoidance of unsuitable surface conditions must be seen as the most likely factor explaining the colonization of subterranean habitats by the majority of gastropod species. Local surface habitats are constantly changing and gastropod populations continuously feature the risk of extinction (Régnier et al. 2009). Because temperature and humidity levels in caves demonstrate rather low fluctuations and are generally buffered compared to the surface (Pipan et al. 2011), dwelling in the entrance zone may allow survival in patchy microhabitats (Poulson \& White 1969). Hence, the risk of temporal or seasonal suffering from unsuitable environmental conditions can be locally decreased. By studying the Mediterranean helicid snail Iberus gualtieranus gualtieranus, MorenoRueda (2007) has found evidence for summer survival of this species in karstic crevices. Since slugs are particularly prone to desiccation, increased humidity levels in the subterranean milieu may ensure survival during droughts. Gunn (1992) showed that soil-dwelling is a common response of Boettgerilla pallens to escape direct light exposure and potentially heat. On the other site, winter freezing especially affects slugs and larger gastropods (Getz 1959; Biannic \& Daguzan 1993; Ansart et al. 2001; Cook 2004). The frequent penetration of underground habitats by slugs (e.g. Arion, Boettgerilla, Limax) and helicids (Cepaea and Helix) in the study area may be best explained as a response to winter frost using the subterranean environment as a hibernation site.

Despite temporal or seasonal survival, subterranean habitats may act as long-term refugia at the edge of a species distribution range. The northern range limit of the Mediterranean snail Pomatias elegans is connected with the $2{ }^{\circ} \mathrm{C}$ January isotherm line. Hibernating specimens can withstand frost down to $-6^{\circ} \mathrm{C}$ for several days (Welter-Schultes 2012). In this study, several geographically restricted populations of $P$. elegans were found in the region of Treffurt at the NW-margin of the Thuringian Basin (i.e. at the NE-boarder of the HES state register). During a single visit, up to twelve individuals were collected from the soil populating the entrance and transition zone. More general, peripheral populations surviving in patchy subterranean microhabitats at the edge of a species distribution range can serve as an origin for future range expansion (thereby, significantly increasing the speed of colonization). Additionally, those populations are particularly susceptible to adapt to local environmental conditions because of an increased genetic isolation and/or enhanced/divergent selective pressures 
(Sexton et al. 2009; Vergeer \& Kunin 2013). Two other cave-penetrating gastropods possessed their range limits within the study area: the Scandinavian slug Arion ater (S-range limit) and Phenacolimax major (NE-range limit), the latter being rare east of the Rhine River (Renker et al. 2013).

Finally, one must be cautious to link species observations with their ecological requirements. As an example, frequent observations of living specimens in the dark zone do not necessarily reflect a cave-dwelling ecology of the species as best illustrated by the situation of Discus rotundatus. This abundant species was usually found above-ground or within in the entrance zone of subterranean environments comprising $20 \%$ of all re- cords. However, and because of their sheer number, numerous specimens were also collected in the dark zone ( $12 \%$ of all dark zone observations). As a fungivorous species, $D$. rotundatus may be able to survive in the dark zone for a longer period of time (Renker et al. 2013). Nevertheless, their presence is most probably best explained by population density as some specimens of this highly abundant, cave-penetrating species (Reiss et al. 2009b) will "end up" in the dark zone. Because eco-classifications of cave-dwellers are inferred from the relationship of the animal to the subterranean environment (Sket 2008) and this relationship is reconstructed from observation and species abundance data, one might face a general problem.

\section{CONCLUSIONS}

Subsurface distribution data is paramount to reconstruct species affinities to subterranean habitats, since behavioral and ecological changes may precede morphological change. In this study, several gastropod species were observed from different subterranean light zones possessing a variety of reasons to explain their underground appearance (e.g. exploitation of alternative food sources, aphotic above-ground movement, mating site, temporal, seasonal and long-term refugia, and chance). These individual patterns are important to consider when reconstructing the evolutionary history of subterranean animals and addressing the question of what has caused animals to enter subterranean environments. Finally, the presented data imply the frequent migration of terrestrial gastropod species between the interconnected light zones and the surface. This knowledge may shed light on the origin and importation of allochthonous resources in cave environments (Souza-Silva et al. 2012; Boch et al. 2013). Cave-penetrating gastropods as well as their progeny (incl. deposited egg clutches and the newly hatched juveniles) may end up as nutrients for the cave community.

\section{ACKNOWLEDGEMENTS}

I thank Stefan Zaenker and Dieter Weber for providing the data of their biospeleological collections, Klaus Bogon for his pictures of gastropods and Hannah Schweyen as well as Peter Trontelj for valuable discussions on the topic.

\section{REFERENCES}

Ansart, A., Vernon, P. \& J. Daguzan, 2001: Freezing tolerance versus freezing susceptibility in the land snail Helix aspersa (Gastropoda: Helicidae).- CryoLetters, 22, 3, 193-190.
Biannic, M. \& J. Daguzan, 1993: Cold-hardiness and freezing in the land snail Helix aspersa Müller (Gastropoda; Pulmonata).- Comparative Biochemistry and Physiology Part A: Physiology, 104, 3, 503-506. 
Bichuette, M.E. \& E. Trajano, 2003: Epigean and subterranean ichthyofauna from the São Domingos karst area, Upper Tocantins River basin, Central Brazil.Journal of Fish Biology, 63, 5, 1100-1121.

Boch, S., Prati, D., Werth, S., Rüetschi, J. \& M. Fischer, 2011: Lichen Endozoochory by Snails. PLoS ONE 6, 4, e18770.

Camp, C.D. \& J.B. Jensen, 2007: Use of twilight zones of caves by plethodontid salamanders.- Copeia, 2007, 3, 594-604.

Cook, R.T., 2004: The tolerance of the field slug Deroceras reticulatum to freezing temperatures.- CryoLetters, 25, 3, 187-194.

Cooper, S.J.B., Bradbury, J.H., Saint, K.M., Leys, R., Austin, A.D. \& W.F. Humphreys, 2007: Subterranean archipelago in the Australian arid zone: mitochondrial DNA phylogeography of amphipods from central Western Australia.- Molecular Ecology, 16, 7, 1533-1544.

Culver, D.C., Pipan, T. \& K. Schneider, 2007: Vicariance, dispersal, and scale in the aquatic subterranean fauna of karst regions.- Freshwater Biology, 54, 4, 918-929.

Culver, D.C. \& T. Pipan, 2009: Biology of Caves and Other Subterranean Habitats.- Oxford University Press, pp. 276, Oxford.

Daxl, R., 1967: Ein Beitrag zur Biologie von Boettgerilla vermiformis Wiktor, 1959.- Zeitschrift für angewandte Zoologie, 54, 227-231.

Fauna Europaea, 2012: Fauna Europaea version 2.5.[Online] Available from: http://www.faunaeur.org [Accessed $3^{\text {rd }}$ March 2013].

Getz, L.L., 1959: Notes on the Ecology of Slugs: Arion circumscriptus, Deroceras reticulatum, and D. leave. American Midland Naturalist, 61, 2, 485-498.

Gunn, A., 1992: The ecology of the introduced slug Boettgerilla pallens (Simroth) in North Wales.- Journal of Molluscan Studies 58, 4, 449-453.

Hausdorf, B., 2002: Introduced land snails and slugs in Colombia.- Journal of Molluscan Studies 68, 2, 127-131.

Heller, J. \& A. Dolev, 1994: Biology and population dynamics of a crevice-dwelling landsnail, Cristataria genezarethana (Clausiliidae).- Journal of Molluscan Studies, 60, 1, 33-46.

Howarth, F.G. \& H. Hoch, 2005: Adaptive shifts. In: D.C. Culver \& W.B. White, eds. Encyclopedia of caves, pp. 492-495. Elsevier/Academic Press, Amsterdam, The Netherlands.

Juan, C., Guzik, M.T., Jaume, D. \& S.J.B. Coopers, 2010: Evolution in caves: Darwin's 'wrecks of ancient life' in the molecular era.- Molecular Ecology, 19, 18, 3865-3880.
Leys, R., Watts, C.H.S., Cooper, S.J.B. \& W.F. Humphreys, 2003: Evolution of subterranean diving beetles (Coleoptera: Dytiscidae: Hydroporini, Bidessini) in the arid zone of Australia.- Evolution, 57, 12, 2819 2834.

Moreno-Rueda, G. 2007: Refuge selection by two sympatric species of arid-dwelling land snails: Different adaptive strategies to achieve the same objective.Journal of Arid Environments, 68, 4, 588-598.

Pipan, T., López, H., Oromí, P., Polak, S. \& D.C. Culver, 2011: Temperature variation and the presence of troglobionts in terrestrial shallow subterranean habitats.- Journal of Natural History, 45, 3-4, 253 273.

Poulson, T.L. \& W.B. White, 1969: The cave environment.- Science, 165, 3897, 971-981.

Protas, M. \& W.R. Jeffery, 2012: Evolution and development in cave animals: from fish to crustaceans.Wiley Interdisciplinary Reviews: Developmental Biology, 1, 6, 823-845.

Régnier, C., Fontaine, B. \& P. Bouchet, 2009: Not Knowing, Not Recording, Not Listing: Numerous Unnoticed Mollusk Extinctions.- Conservation Biology, 23, 5, 1214-1221.

Reise, H., Hutchinson, J.M.C., Forsyth, R.F. \& T. Forsyth, 2000: The ecology and spread of the terrestrial slug Boettgerilla pallens in Europe with reference to its recent discovery in North America.- The Veliger, 43, 4, 313-318.

Reiss, M., Zaenker, S. \& H. Steiner, 2009a: The biospeleological register of the Hesse Federation for Cave and Karst Research (Germany).- Cave and Karst Science, 35, 1, 25-34.

Reiss, M., Zaenker, S. \& G. Stein, 2009b: Höhlen als Lebensräume in Hessen - Erfassung, Bewertung und Schutz subterraner Ökosysteme.- Naturschutz und Landschaftsplanung, 41, 6, 165-172.

Renker, C., Weber, D. \& A. Pohl, 2012: Gastropods of caves in the Grand Duchy of Luxembourg.- American Malacological Society $78^{\text {th }}$ Annual Meeting. 16.-21.6.2012, Cherry Hill, New Jersey.

Renker, C., Weber, D. \& A. Pohl, 2013: Schnecken (Mollusca, Gastropoda) aus Höhlen des Großherzogtums Luxemburg.- Ferrantia, 69, 96-107.

Sexton, J.P., McIntyre, P.J., Angert, A.L. \& K.J. Rice, 2009: Evolution and Ecology of Species Range Limits.Annual Review of Ecology, Evolution, and Systematics, 40, 415-436.

Sket, B., 2008: Can we agree on an ecological classification of subterranean animals?- Journal of Natural History, 42, 21-22, 1549-1563. 
Souza-Silva, M., Ferreira de Oliveira Bernardi, L., Parentoni Martins, R. \& R. Lopes Ferreira, 2012: Transport and consumption of organic detritus in a neotropical limestone cave.- Acta Carsologica, 41, 1, 139-150.

Vergeer, P. \& W.E. Kunin, 2013: Adaptation at range margins: common garden trials and the performance of Arabidopsis lyrata across its northwestern European range.- New Phytologist, 197, 3, 989-1001.

Von Proschwitz, T., 1994: Oxychilus cellarius (Müller) and Oxychilus draparnaudi (Beck) as predators on egg-clutches of Arion lusitanicus Mabille.- Journal of Conchology, 35, 183-184.

Weber, D. 2012: Die Höhlenfauna und -flora des Höhlenkatastergebietes Rheinland-Pfalz/Saarland, 5. Teil.- Abhandlungen zur Karst- und Höhlenkunde, $36,1-2367$.
Weigand, A.M., Jochum, A., Slapnik, R., Schnitzler, J., Zarza, E. \& A. Klussmann-Kolb, 2013: Evolution of Microgastropods (Ellobioidea, Carychiidae): Integrating taxonomic, phylogenetic and evolutionary hypotheses.- BMC Evolutionary Biology, 13, 18.

Welter-Schultes, F.W., 2012: European non-marine molluscs, a guide for species identification.- Planet Poster Editions, pp. 760, Göttingen.

Zaenker, S., 2008: Das Biospeläologische Kataster von Hessen.- Abhandlungen zur Karst- und Höhlenkunde, 32, updated till 12.04.2008. 